\title{
INNOVATIVE BUSINESS PLAN MODELLING WITH A VIEW TO IMPROVING THE EFFICIENCY OF THE INNOVATION MANAGEMENT PROCESS
}

\section{Klipkova Oksana ${ }^{1}$}

DOI: https://doi.org/10.30525/978-9934-571-89-3_129

Formation of market cooperation of subjects of innovation activity, including the first and the last stages of innovative project development, is based on identifying the main basic fundamentals of business mechanism for forming the system of enterprise innovative development, which is best reflected in the process of modelling innovation management in the form of an innovative business plan.

The innovative business plan should take into account the degree of innovation of a product, which will determine the direction of marketing research, internal firm analysis of technical and economic opportunities of the enterprise, and risk assessment.

The model should be formed by the system "conditions-tools-organization" of innovative development. The block "organization of innovative development" will consider all stages of the innovation process as the implementation [1, p. 170].

Creating an innovative business plan enlarges most of the disadvantages of a regular business plan:

1. The business plan in the theoretical design involves the filling of several large sections, the compulsory formation of them may increase the research, ensure the availability of inaccurate, lagged, and aggregated information that is not yet fully

\footnotetext{
${ }^{1}$ Institute of Innovative Education,

Kyiv National University of Construction and Architecture, Ukraine
} 
specified for the innovative idea, and this will lead to a large number of research iterations.

2. Execution of a large number of tasks in each section provides for an increase in the number of impact factors, leads to the modification of the idea and the loss of its relevance.

3. Cumbersomeness of a business plan can lead to the transformation of the original idea into another concept and, accordingly, the need to work out a few variants.

In order to identify the novelty of the product, it is worth using the "productmarket" matrix, which will help to identify the benchmark for writing an innovative business plan.

After analysing the matrix, the entrepreneur can determine the goals of the enterprise's innovation strategy and release the innovative business plan from unnecessary studies [2, p. 182].

The idea of an innovative business plan can be provoked by own needs in the resources, needs and tasks of the state and municipal authorities.

Special principles take into account the features of creating a certain type of innovation project and the level of needs satisfaction. These include profitability, level of efficiency, and degree of achievement of innovative strategic goals of the enterprise and its investment attractiveness.

Principles of forming an innovative business plan of the enterprise consider systematic and complex nature of the organization, making compromise decisions in the process of choosing an idea, satisfying consumer needs, the flexibility of the system, and orientation to the innovative way of development.

The content of a typical innovative business plan includes the following sections:

1. Summary. This section defines the main idea of implementing an innovation project, identifies key stakeholders.

2. Enterprise. This section covers information about the place of implementation of the innovation project (advantages and disadvantages), the main events that will affect the operating result, specify the size of the authorized capital, information about those depositors holding controlling stakes and those having a stake of more than $5 \%$.

3. Products. The main focus of the section is made on the exclusivity of the new product, its distinction from the existing in the market.

4. The analysis of the market of products involves assessing the potential demand for the innovative product of the enterprise.

5. Competition. The section provides an analysis of the information about the potential competitive environment, the probable strategies of competitors and their technical and economic capabilities to enter the market with a similar product.

6. Marketing. The purpose and strategy of innovation marketing are here determined. The complex of marketing is formed, the budget of the marketing service is determined.

The definition, in our opinion, is not entirely complete since the marketing communication environment is determinant but not the only factor determining the market success of the commercialization of innovation. 
The conduct of patent and marketing researches of innovation activity makes them an integral part of the process of innovation management in the system of innovative development of the enterprise and determines the benchmarks for an innovation strategy developed at the enterprise.

7. Production process. The section is based on information on the description of the technological process.

8. Organizational plan. It contains the provisions on the construction of an organizational structure, an employee incentive programme, a calendar plan of the newly created enterprise.

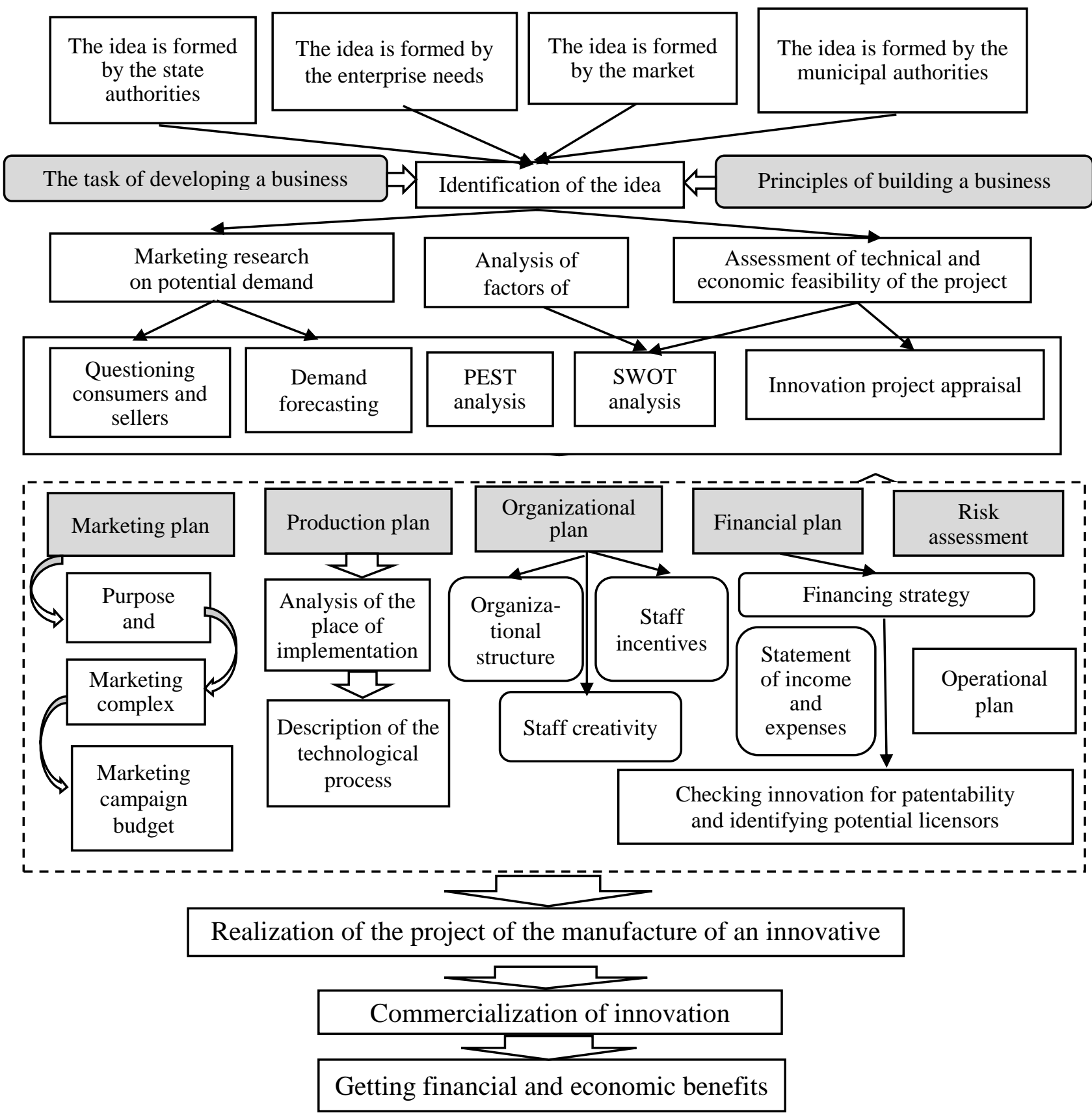

Figure 1. Innovative business plan model in the process of innovation management Source: developed by the author based on [3, p. 238] 
9. Risk assessment. It includes a list of possible risks for implementing an innovative business plan, ranking them in descending order of the probability. The relevance of this section is determined by the uncertainty of information about the environment for the realization of innovative products.

10. Financial plan. It consists of the innovative project's funds flow statement. We believe that particular attention should be paid to different types of costs associated with the place of implementation of innovation.

Designing an innovative project, taking into account marketing, organizational, technical, and creative principles, is intended to solve tactical and strategic tasks in close interaction of the organizational units with a long-term focus. On this basis, one can develop a model of the innovative business plan of the innovation process (Figure 1).

Each phase of the lifecycle of an innovation project involves the presence of its participants and the list of works. A formation of the amount of costs and a preliminary assessment of innovation from idea to commercial implementation in the form of a product or its documentary form as a patent take place at each stage.

The organization of the system of innovative development under fierce competition of enterprises for the best conditions of production and sale is possible only due to creative search, innovative culture, and the creative system which stimulates it. The creative component of the system is integrated into innovative culture formed on the basis of organization and is based on the principles of creativity of management activity, which in the future will ensure the commercial success of innovation, regardless of the ways of use.

\section{References:}

1. Zakharchyn H. M., Andriichuk Yu. A. (2012). Planuvannia innovatsiinoi diialnosti: alternatyvy i etapy [Planning of innovation activity: alternatives and phases]. Actual economic problems, no 5, pp. 169-175.

2. Kataiev A. H., Herbut M. V. (2011). Rozrobka biznes-planu vyrobnytstva novykh tovariv [Development of Business plan for new products production]. "Lviv Polytechnic" Bulletin, no. 698, pp. 180-190.

3. Kutsyk V. I., Klipkova O. I. (2017). Komertsializatsiia ob'iektiv intelektualnoi vlasnosti kreatyvnykh industrii innovatsiinykh system rozvytku [Commercialisation of intellectual Property objects of creative industries innovative development systems]. Lviv : Vydavnytstvo Lvivskoho torhovelno-ekonomichnoho universytetu. (in Ukrainian) 